\title{
2. Adding perphenazine to increase effectiveness of standard glioblastoma chemoirradiation.
}

\author{
Richard Kast ${ }^{1}$ \\ ${ }^{1}$ IIAIGC Study Center
}

June 22, 2020

\begin{abstract}
In the effort to improve treatment effectiveness in glioblastoma, this short note reviewed collected data on the pathophysiology of glioblastoma with particular reference to intersections with the pharmacology of perphenazine. That study identified five areas of potentially beneficial intersection. Data showed seemingly 5 independent perphenazine attributes of benefit to glioblastoma treatment - i) blocking dopamine receptor 2, ii) reducing centrifugal migration of subventricular zone cells by blocking dopamine receptor 3, iii) blocking serotonin receptor 7, iv) activation of protein phosphatase 2, and v) nausea reduction. Perphenazine is fully compatible with current chemoirradiation protocols and with the commonly used ancillary medicines used in clinical practice during the course of glioblastoma. All these attributes argue for a trial of perphenazine's addition to current standard treatment with temozolomide and irradiation. The subventricular zone seeds the brain with mutated cells that become recurrent glioblastoma after centrifugal migration. The current paper shows how perphenazine might reduce that contribution. Perphenazine is an old, generic, cheap, phenothiazine antipsychotic drug that has been in continuous clinical use worldwide since the 1950's. Clinical experience and research data over these decades have shown perphenazine to be well-tolerated in psychiatric populations, in normals, and in non-psychiatric, medically ill populations for whom perphenazine is used to reduce nausea. For now (Summer, 2020) the nature of glioblastoma requires a polypharmacy approach until/unless a core feature and means to address it can be identified in the future. Conclusions: Perphenazine possesses a remarkable constellation of attributes that recommend its use in GB treatment.
\end{abstract}

2. Adding perphenazine to increase effectiveness of standard glioblastoma chemoirradiation.

R. E. Kast, MD

IIAIGC Study Center

11 Arlington $\mathrm{Ct}$

Burlington, Vermont

05408 USA

richarderickast@gmail.com

ORCID 0000-0002-7876-0400

16 June 2020

ABSTRACT

In the effort to improve treatment effectiveness in glioblastoma, this short note reviewed collected data on the pathophysiology of glioblastoma with particular reference to intersections with the pharmacology of perphenazine. That study identified five areas of potentially beneficial intersection. Data showed seemingly 5 independent perphenazine attributes of benefit to glioblastoma treatment - i) blocking dopamine receptor 2, 
ii) reducing centrifugal migration of subventricular zone cells by blocking dopamine receptor 3, iii) blocking serotonin receptor 7 , iv) activation of protein phosphatase 2 , and v) nausea reduction. Perphenazine is fully compatible with current chemoirradiation protocols and with the commonly used ancillary medicines used in clinical practice during the course of glioblastoma. All these attributes argue for a trial of perphenazine's addition to current standard treatment with temozolomide and irradiation. The subventricular zone seeds the brain with mutated cells that become recurrent glioblastoma after centrifugal migration. The current paper shows how perphenazine might reduce that contribution. Perphenazine is an old, generic, cheap, phenothiazine antipsychotic drug that has been in continuous clinical use worldwide since the 1950's. Clinical experience and research data over these decades have shown perphenazine to be well-tolerated in psychiatric populations, in normals, and in non-psychiatric, medically ill populations for whom perphenazine is used to reduce nausea. For now (Summer, 2020) the nature of glioblastoma requires a polypharmacy approach until/unless a core feature and means to address it can be identified in the future. Conclusions: Perphenazine possesses a remarkable constellation of attributes that recommend its use in GB treatment.

Keywords: dopamine; glioblastoma; perphenazine; protein phosphatase 2A; serotonin; subventricular zone;

Abbreviations: dopamine receptor 2 (D2); glioblastoma (GB); serotonin or serotonergic (5-HT); trimeric protein phosphatase $2 \mathrm{~A}(\mathrm{PP} 2 \mathrm{~A})$;

1. Introduction:

There has been little progress in treating glioblastoma (GB) since the introduction circa 2005 of temozolomide to the, then standard, resection and irradiation. This paper addresses the rationale for adding perphenazine to current GB treatment. By reviewing recent data on the pathophysiology of GB with specific reference to intersections with the pharmacodynamic attributes of perphenazine, this paper identified five areas of potentially beneficial intersection. Strong empirical evidence for perphenazine's, and related D2 blocking drugs', ability to reduce GB growth is also presented.

Perphenazine is a 404 Da brain-penetrant, cheap, generic drug, approved for use in humans worldwide. It has been in continuous use since the 1950's to treat psychotic states and conditions $[1,2]$. Perphenazine is also used to reduce nausea [3], or to calm people who are in an acutely disorganized agitated state. It also has adjunctive use in treating depression. Basic pharmacologic parameters of perphenazine are listed in Table 1 .

Its antipsychotic properties are thought to be due to blockage of, or inducing reduced activity of, signaling at the dopamine receptor 2 (D2). Perphenazine also exerts inhibitory activity at selected serotonergic (5HT) receptors that contribute to its adjunctive effects in treating depression. Table 2. lists the currently FDA/EMA approved and marketed D2 blocking drugs used to treat psychosis that, remarkably, all also happen to have a clinical or preclinical research database showing activity in inhibiting glioma growth. The potential for clinical benefit of D2 blockade with approved and marketed anti-psychotic drugs as part of treatment of GB was recently reviewed by four different groups [4-7].

This short paper examined published data on areas of intersection between the documented pharmacodynamic attributes of perphenazine and other marketed D2 blocking drugs generally and what we know about the pathophysiology of GB growth and GB's treatment resistance.

2. GB and dopamine:

Human GB biopsy tissue has increased D2 mRNA and protein expression compared to normal brain tissue. The four recent reviews mentioned above discussed in detail many of the pathways by which D2 blocking antipsychotic medicines act to inhibit GB growth [4-7]. D2 blocking also has been discussed as a potential treatment in cancer generally [8-10].

Dopamine signals via 5 different receptors, D1 to D5. Although they each have distinct attributes, they also share certain commonalities. Human GB cells synthesize and secrete dopamine [5]. Signaling at D2 increases 
GB stem attributes, stimulates growth, and increases their reliance on glycolysis [5]. Perphenazine inhibits both D2 and D3 receptors.

3. GB and need for polypharmacy:

3.1. GB cells use a variety of metabolic energy generation paths that to varying degrees cross-cover for each other [11, 12]. Drug repurposing allows use of well-known older drugs that, while not cytotoxic in themselves, are able to block GB survival and growth pathways. GB cells after all, like other cancers, use normal, physiologic growth signals to thrive, albeit abnormally applied.

3.2. GB like other treatment resistant cancers is a community of mutually supporting subclones [13]. Horizontal communication of resistance exists via double minutes, exosomes, cell fusions, and other means. Disrupting that mutually supporting communication between the subclones, is required for "proper functioning" of the tumor subclones for optimal growth. Thus inhibiting that communication is one path for tumor control.

3.3. GB's extreme temporal and spatial heterogeneity with multiple cross-covering, growth-driving systems, combined with a uniquely robust motility with consequent wide tissue invasion [14-16] all must be simultaneously blocked - and kept blocked over time - to retard or stop GB growth.

3.4. Growth driving systems in GB are moving targets, evolving over time and responding to our treatment interventions $[17,18]$. Also stem cells within a cancer likewise are not a stable clonally related population [19]. Stemness is an attribute that can be lost in daughter cells of stem cells, or gained by daughter cells of stem-marker negative cells [19]. Stemness is a fluid attribute. For these reasons - and the failure over the last 40 years of several hundred clinical GB studies of various cytotoxic drugs or drugs that blocked single growth driving systems - we believe a polypharmacy approach is needed. D2 blocking will be an important part of that polypharmacy for GB.

3.5. A guiding principle behind the development of more effective GB treatment is the concept used in military planning of clearly identifying and individually addressing the different requirements for A) a main operation, and B) shaping operations (note pleural). The main operation commonly is aimed at destruction of enemy forces. In our case - killing GB cells. Supporting operations are all activities directed at matters peripheral to the main effort, but that are designed to help the main effort succeed. A military example would be destroying a bridge enemy forces might use to bring in reinforcements to where the main operation is occurring.

In GB treatment this concept must be applied in crafting our treatment regimen. This paper shows how adding perphenazine has five attributes that would qualify it as a worthwhile shaping operation to current main operations of surgery, temozolomide and irradiation.

3.6. Let the 2011 study in recurrent GB of Hegi et al serve as example of need for shaping operations: In accord with others, they found that $60 \%$ of GB had EGFR gene amplification and that agonist stimulation (phosphorylation) of EGFR in vitro resulted downstream phosphorylation of RAS/MAPK and PI3K/AKT pathways. Gefitinib achieved $\sim 10$ to 20 times higher GB tissue concentrations compared to serum, and effectively prevented EGFR activation (phosphorylation) but had no effect on reducing RAS/MAPK and PI3K/AKT pathways' activation in clinical samples or in a xenograft model. Crucially for our research planning however, they did find effective blocking of downstream RAS/MAPK and PI3K/AKT signaling after in vitro gefitinib exposure [20]. Conclusion from Helgi et al: In vitro GB cell coping paths are not reflective of human disease processes and polypharmacy required to defeat GB's as things now stand.

Elmaci and Altinoz reviewed past data on an old, still-in-use antipsychotic drug, pimozide, and drew the conclusion that it may show GB growth inhibition [21]. Pimozide has similar receptor binding profile as does perphenazine. Pimozide has tighter inhibitory affinity to D2, D3, and calmodulin, but regulatory restrictions in some jurisdictions and risks of QTc prolongation with pimozide would complicate its use in GB. Thus perphenazine. 
In addition to the above reasoning, that a polypharmacy approach will be required, we are planning on adding perphenazine to GB treatment based on fully five perphenazine attributes: i) D2 antagonism, ii) D3 antagonism, iii) 5-HT7 inhibition, iv) de-inhibition (i.e. activation) of trimeric protein phosphatase 2A (PP2A), v) nausea reduction. Details on these mechanisms of action and how they therapeutically beneficially interact with GB pathophysiology, with references, follow below:

4. The findings- GB and D2 antagonism.

Perphenazine has empirical evidence for anti-GB effects. EC50 of perphenazine to GB cells in vitro was 0.98 $\mu \mathrm{mol}$ [22]. However, this is unlikely to be a relevant mechanism of action though, given the nmol range of clinically achievable levels.

We find the data of Table 2 to be remarkable in that 16 structurally different, marketed, clinically used D2 antagonists should each have evidence of anti-glioma effects. In addition to the autocrine growth loop, the existence of which is suggested by GB's expression of both D2 receptors and dopamine [5] we see strong cytotoxic synergy between temozolomide and D2 blockade [23]. That single empirical evidence alone should be enough to warrant a clinical trial of perphenazine. In addition to the 16 marketed anti-psychotic medicines of Table 2, several experimental, not-yet-marketed D2, D3, and D4 antagonists like Lcc-09 and ONC201 also have demonstrated GB cell killing effects and are being actively pursued for GB treatment [24-26].

Psychosis is one of the most common major malfunctions of humans in all societies worldwide. Because of this, and the general applicability of D2 antagonism in stopping overt psychosis, we have 20 antipsychotic, D2 inhibiting medicines currently marketed in most jurisdictions.

GB spheroid growth in vitro is inhibited by several clinically used D2 antagonists and stimulated by specific D2 agonists [30]. Paths by which D2 antagonism augments temozolomide and other common cancer chemotherapeutic drugs was recently reviewed by Shaw et al, and demonstrated specifically for temozolomide in GB by Liu et al. [31, 23].

The experimental D2 antagonist, ONC201, has just completed a phase 1 clinical trial in recurrent GB with evidence of good tolerability but little general activity as single agent, although there was one durable remission in an H3K27 mutated case [26].

5. The Findings- D3 antagonism and the SVZ.

Yoon et al early in 2020 distinguished a clear distinction between post-resection GB as originating from centrifugally migrating subventricular zone cells (SVZ) versus recurrences from already present residual cells within brain tissue that had migrated - invaded - brain from the original tumor mass [17]. Collected data below indicate that perphenazine will reduce centrifugal migration of SVZ cells, malignant or non-malignant.

SVZ cells line the lateral ventricles in a ribbon just distal to the hypocellular gap [32]. These SVZ cells are one of the very few areas of the adult brain that give rise to new neurons. Robust data show that SVZ contributes to GB growth, with strong indications that indeed adult GB tends to originate from a malignantly transformed SVZ cell or cell group [17, 33-42]. Indeed, recent evidence indicates that malignant transformation of nonmalignant cells of the SVZ is the primary initiating event from which the cell of origin many human GBs migrate [17, 43, 44]. Such cells are particularly resistant to TMZ and irradiation due to an abundance of anti-apoptotic Bcl-2 and Mcl-1 [45]. Normal, non-malignant neural stem cells residing in the SVZ are highly motile, and exhibit normal migratory patterns reminiscent of Scherer's structures in GB [46]. Contact with the SVZ is a poor prognosis sign independent of the molecular GB subtype [34, 47].

The SVZ neurons or neuron-like cells replicate throughout life. They also centrifugally migrate throughout life. Both normal SVZ cells and malignant transformed SVZ GB cells proliferate and centrifugally migrate in response to dopaminergic signals, and particularly, specifically, dopaminergic signals at the D3 receptor [33-38, 40, 48]. Hence perphenazine to inhibit D3 driven contributions to GB from the SVZ.

6. The Findings- blocking 5-HT7. 
5-HT is remarkable in that all Animalia studied use 5-HT in similar or analogous ways. In both invertebrates and vertebrates, 5-HT tends to potentiate or mitigate neuronal activity rather than to start, stop or trigger a specific behavior [49]. 5-HT tends to exert a behavioral fine-tuning effect from crabs to primates.

Of the dozen or so 5-HT receptors currently recognized, 5-HT receptor 7 (5-HT7) is expressed on GB cells where agonism enhances growth [50-52]. This same finding of growth drive stimulation via 5-HT7 is also found in non-small cell lung adenocarcinoma where 5-HT7 agonism drives proliferation, migration, and invasion [53]. Similar growth stimulation by 5 -HT7 was seen in neuroendocrine tumors [54], hepatocellular carcinoma [55], and triple negative breast cancer [56, 57]

\section{The Findings- De-inhibition of PP2A.}

PP2A is a trimeric serine-threonine phosphorylase, with a scaffolding subunit, a catalytic subunit, and a regulatory subunit with multiple subunits isoforms, resulting in over 60 combinations [58, 59]. Half a dozen inhibitory peptides are recognized. PP2A dephosphorylates many of the substrates phosphorylated by receptor kinases (examples: c-MYC, AKT, Cdc25, Bax, and GSK3) active in driving cancers' growth [58]. Phosphorylation of PP2A itself can inactivate it. Importantly for use in GB, phenothiazines generally, and perphenazine specifically, activate (de-inhibit) PP2A [59, 60].

So common a finding in various cancers is diminished PP2A activity that subnormal PP2A has been termed "the broken off switch in cancer" $[61,62,63,64]$. PP2A, as a phosphatase, removes a phosphate from phosphorylated kinases, many of which drive GB growth and many of which become inactivated by such dephosphorylation [65, 66]. Advantages of activating (de-inhibiting) PP2A during cancer treatment with kinase inhibitors was recently reviewed by Westermarck et al [67, 68].

Multiple cell surface receptor kinases phosphorylate PIP2 to PIP3. PTEN reverses that process, dephosphorylating PIP3 to PIP2.

PIP3 phosphorylates AKT, which itself then becomes an active kinase. Higher level phosphorylated AKT correlates with shorter survival in GB. Upregulation of PI3K/AKT pathway has also been documented in GM stem cells. AKT phosphorylates several growth promoting cytosol targets in GB, thus forming a growth driving signaling node contributing to multiple malignant behaviors of GB [27, 28, 29]. As an important example, PP2A dephosphorylates AKT, inactivating it in glioma cells $[69,70]$. AKT phosphorylation is a central signaling hub in phosphorylation chains upon which growth signals from several receptors converge that are required for GB mitosis entry [71].

PTEN and AKT are so fundamental to the normal functioning of all nucleated cells that straight inhibition of AKT seems less promising than simply calming it down, moderating it, reducing the hyperactivation seen in GB.

Because so many outer cell membrane signaling receptors converge on AKT, effect of blocking one or two of them can leave other receptors to cross cover for the blocked ones (our Nile Distributary Problem).

PP2A dephosphorylates proto-oncogene basic helix-loop-helix transcription factor (MYC) resulting in a more rapid degradation of MYC leaving less time for it to act [72]. MYC is often overactive in driving GB growth $[73,74]$.

PP2A also dephosphorylates Bax, enhancing its pro apoptosis function [75]. Inhibition of PP2A is required for increasing phosphorylation of Wee1, Myt1, and Cdc25, which are in turn required for mitosis entry [59]. We reason that since perphenazine is widely used around the world to treat psychosis, without evidence of mitosis prevention, that the disinhibition of PP2A it exerts must be only partial or at least partially circumventable.

PP2A dephosphorylation of MYC might also be of interest in immunotherapy of GB and other cancers in that MYC transactivates PD-1 ligand [60]. Dephosphorylated MYC is rapidly degraded so lowering MYC dwell time might thereby lower PD-1 immunoinhibitory function. 
Perphenazine has demonstrated tumor growth retarding effects via PP2A activation in lymphoma [76], acute lymphocytic leukemia [77], acute myeloid leukemia [78]. Importance of activating PP2A during GB treatment was recently reviewed [62]. PP2A activating perphenazine derivatives are in active development to treat several cancers and have demonstrated preclinical activity $[79,80]$.

8. The Findings- Anti-nausea effects of perphenazine.

Nausea is common during treatment of GB. Although standard current treatment with irradiation and temozolomide is not highly emetogenic, nausea does occur and does shorten progression free survival when it occurs [81, 82]. Perphenazine reduces nausea and has a long history of use for that purpose, dating from the 1960's [83-88]. Perphenazine is used as one of several drugs in modern anti-nausea regimens during chemotherapy particularly when one is aiming for "zero tolerance" [87]. Perphenazine and other D2 inhibiting drugs are non-inferior to the more modern drugs of the "setron group (like ondansetron, granisetron, etc) [3, 88]. Anti-nausea effects of perphenazine are additive with 5-HT3 antagonists, NK-1 antagonists and steroids. Given the distress of even grade 1 or 2 nausea or vomiting, perphenazine's good tolerability, and the multiple potential areas of anti-GB growth effects, a trial of perphenazine $8 \mathrm{mg} \times 1$ at h.s. added to standard Stupp chemoirradiation right from day 1 of treatment is warranted.

9. Potential risks of perphenazine.

Side effects from perphenazine tend to be dose related and are not common below $6 \mathrm{mg} /$ day. Parkinsonian signs or symptoms (bradykinesia, akinesia, tremor, diminished motor fluidity), or daytime sedation are progressively more frequently seen as dose exceeds $8-12 \mathrm{mg} /$ day but are fully and rapidly reversible upon dose lowering.

More serious but also readily reversible with medical treatment followed by dose reduction are neuroleptic malignant syndrome (NMS) and serotonin syndrome. Serotonin syndrome is characterized by confusion, autonomic nervous system instability, neurologic manifestations, and hyperthermia. NMS is estimated to occur in three patients per 10,000 patients treated with D2 blocking medicines [89]. NMS is characterized by a similar clinical picture as serotonin syndrome with elevations of creatine kinase, lactate dehydrogenase, aspartate transaminase), and leukocyte count. These two nominal entities can overlap [90-93]. Formes frustes are far more common than the fully blown, classically defined syndromes. Left untreated these can be fatal but when recognized early, treatment with cessation of the offending drug and supportive measures are commonly enough for rapid resolution, although more active reversal medical treatments are available [94].

Tardive dyskinesia is a late adverse effect seen occasionally after decades of any D2 inhibitor's use. Tardive dyskinesia tends to be treatable but irreversible. Perphenazine is one of the four commonly used D2 blocking drugs for which routine drug level monitoring is recommended, so blood level testing is widely available [95].

\section{Conclusions.}

GB has been an intractable cancer with short survival after diagnosis despite current standard treatment efforts. It seems polypharmacy will be required for long-term control of GB growth until we find a core core feature of GB growth and the means to address that core feature. Perphenazine is an old, generic, and well-studied drug. Most clinicians around the world regardless of their specialty are familiar with it. This article assembled data on five areas where the biochemical and physiological attributes of perphenazine intersected with those of GB in ways that might be expected to impede GB's resistance to current treatment.

Acknowledgements:

There are no conflicts of interest in any matter related to this work. There was no funding for this work.

\section{References.}

1. Rosenheck R, Lin H. Noninferiority of perphenazine vs. three second-generation antipsychotics in chronic schizophrenia. J Nerv Ment Dis. 2014;202(1):18-24. doi:10.1097/NMD.0000000000000065. 
2. Chrisphonte P, Ostroff RB, Rosenheck RA. Perphenazine suspension: a new, old treatment, side effects and continuous use. Psychiatr Q. 2012;83(3):335-41. doi:10.1007/s11126-011-9203-1.

3. Holder-Murray J, Esper SA, Boisen ML, Gealey J, Meister K, Medich DS, Subramaniam K. Postoperative nausea and vomiting in patients undergoing colorectal surgery within an institutional enhanced recovery after surgery protocol: comparison of two prophylactic antiemetic regimens. Korean J Anesthesiol. 2019;72(4):344-350. doi:10.4097/kja.d.18.00355.

4. Kamarudin MNA, Parhar I. Emerging therapeutic potential of anti-psychotic drugs in the management of human glioma: A comprehensive review. Oncotarget. 2019;10(39):3952-3977. doi:10.18632/oncotarget.26994.

5. Caragher SP, Shireman JM, Huang M, Miska J, Atashi F, Baisiwala S, Hong Park C, Saathoff MR, Warnke L, Xiao T, Lesniak MS, James CD, Meltzer H, Tryba AK, Ahmed AU. Activation of Dopamine Receptor 2 Prompts Transcriptomic and Metabolic Plasticity in Glioblastoma. J Neurosci. 2019;39(11):1982-1993. doi:10.1523/JNEUROSCI.1589-18.2018.

6. Lee JK, Nam DH, Lee J. Repurposing antipsychotics as glioblastoma therapeutics: Potentials and challenges. Oncol Lett. 2016;11(2):1281-1286. doi:10.3892/ol.2016.4074.

7. Rundle-Thiele D, Head R, Cosgrove L, Martin JH. Repurposing some older drugs that cross the bloodbrain barrier and have potential anticancer activity to provide new treatment options for glioblastoma. $\mathrm{Br}$ J Clin Pharmacol. 2016;81(2):199-209. doi:10.1111/bcp.12785.

8. Hendouei N, Saghafi F, Shadfar F, Hosseinimehr SJ. Molecular mechanisms of anti-psychotic drugs for improvement of cancer treatment. Eur J Pharmacol. 2019;856:172402. doi:10.1016/j.ejphar.2019.05.031.

9. Roney MSI, Park SK. Antipsychotic dopamine receptor antagonists, cancer, and cancer stem cells. Arch Pharm Res. 2018;41(4):384-408. doi:10.1007/s12272-018-1017-3.

10. Weissenrieder JS, Neighbors JD, Mailman RB, Hohl RJ. Cancer and the Dopamine D(2) Receptor: A Pharmacological Perspective. J Pharmacol Exp Ther. 2019;370(1):111-126. doi:10.1124/jpet.119.256818.

11. Le Rhun E, Preusser M, Roth P, Reardon DA, van den Bent M, Wen P, Reifenberger G, Weller M. Molecular targeted therapy of glioblastoma. Cancer Treat Rev. 2019;80:101896. doi:10.1016/j.ctrv.2019.101896.

12. Bernstock JD, Mooney JH, Ilyas A, Chagoya G, Estevez-Ordonez D, Ibrahim A, Nakano I. Molecular and cellular intratumoral heterogeneity in primary glioblastoma: clinical and translational implications. J Neurosurg. 2019:1-9. doi:10.3171/2019.5.JNS19364.

13. Vinci M, Burford A, Molinari V, Kessler K, Popov S, Clarke M, Taylor KR, Pemberton HN, Lord CJ, Gutteridge A, Forshew T, Carvalho D, Marshall LV, Qin EY, Ingram WJ, Moore AS, Ng HK, Trabelsi S, H'mida-Ben Brahim D, Entz-Werle N, Zacharoulis S, Vaidya S, Mandeville HC, Bridges LR, Martin AJ, Al-Sarraj S, Chandler C, Sunol M, Mora J, de Torres C, Cruz O, Carcaboso AM, Monje M, Mackay A, Jones C. Functional diversity and cooperativity between subclonal populations of pediatric glioblastoma and diffuse intrinsic pontine glioma cells. Nat Med. 2018;24(8):1204-1215. doi:10.1038/s41591-018-0086-7.

14. Perrin SL, Samuel MS, Koszyca B, Brown MP, Ebert LM, Oksdath M, Gomez GA. Glioblastoma heterogeneity and the tumour microenvironment: implications for preclinical research and development of new treatments. Biochem Soc Trans. 2019;47(2):625-638. doi:10.1042/BST20180444.

15. Dirkse A, Golebiewska A, Buder T, Nazarov PV, Muller A, Poovathingal S, Brons NHC, Leite S, Sauvageot N, Sarkisjan D, Seyfrid M, Fritah S, Stieber D, Michelucci A, Hertel F, Herold-Mende C, Azuaje F, Skupin A, Bjerkvig R, Deutsch A, Voss-Böhme A, Niclou SP. Stem cell-associated heterogeneity in Glioblastoma results from intrinsic tumor plasticity shaped by the microenvironment. Nat Commun. 2019;10(1):1787. doi:10.1038/s41467-019-09853-z. 
16. Fayzullin A, Sandberg CJ, Spreadbury M, Saberniak BM, Grieg Z, Skaga E, Langmoen IA, Vik-Mo EO. Phenotypic and Expressional Heterogeneity in the Invasive Glioma Cells. Transl Oncol. 2019;12(1):122-133. doi:10.1016/j.tranon.2018.09.014.

17. Yoon SJ, Park J, Jang DS, Kim HJ, Lee JH, Jo E, Choi RJ, Shim JK, Moon JH, Kim EH, Chang JH, Lee JH, Kang SG. Glioblastoma Cellular Origin and the Firework Pattern of Cancer Genesis from the Subventricular Zone. J Korean Neurosurg Soc. 2020;63(1):26-33. doi:10.3340/jkns.2019.0129.

18. Schäfer N, Gielen GH, Rauschenbach L, Kebir S, Till A, Reinartz R, Simon M, Niehusmann P, Kleinschnitz C, Herrlinger U, Pietsch T, Scheffler B, Glas M. Longitudinal heterogeneity in glioblastoma: moving targets in recurrent versus primary tumors. J Transl Med. 2019;17(1):96. doi:10.1186/s12967-019-1846-y.

19. Feng JM, Miao ZH, Jiang Y, Chen Y, Li JX, Tong LJ, Zhang J, Huang YR, Ding J. Characterization of the conversion between CD133+ and CD133- cells in colon cancer SW620 cell line. Cancer Biol Ther. 2012;13(14):1396-406. doi:10.4161/cbt.22000.

20. Hegi ME, Diserens AC, Bady P, Kamoshima Y, Kouwenhoven MC, Delorenzi M, Lambiv WL, Hamou MF, Matter MS, Koch A, Heppner FL, Yonekawa Y, Merlo A, Frei K, Mariani L, Hofer S. Pathway analysis of glioblastoma tissue after preoperative treatment with the EGFR tyrosine kinase inhibitor gefitinib-a phase II trial. Mol Cancer Ther. 2011;10(6):1102-12. doi:10.1158/1535-7163.MCT-11-0048.

21. Elmaci I, Altinoz MA. Targeting the cellular schizophrenia. Likely employment of the antipsychotic agent pimozide in treatment of refractory cancers and glioblastoma. Crit Rev Oncol Hematol. 2018;128:96109. doi:10.1016/j.critrevonc.2018.06.004.

22. Otreba M, Buszman E. Perphenazine and prochlorperazine induce concentration dependent loss in human glioblastoma cells viability. Pharmazie. 2018;73(1):19-21. doi:10.1691/ph.2018.7806.

23. Liu Z, Jiang X, Gao L, Liu X, Li J, Huang X, Zeng T. Synergistic Suppression of Glioblastoma Cell Growth by Combined Application of Temozolomide and Dopamine D2 Receptor Antagonists. World Neurosurg. 2019;128:e468-e477. doi:10.1016/j.wneu.2019.04.180.

24. Wen YT, Wu AT, Bamodu OA, Wei L, Lin CM, Yen Y, Chao TY, Mukhopadhyay D, Hsiao M, Huang HS. A Novel Multi-Target Small Molecule, LCC-09, Inhibits Stemness and Therapy-Resistant Phenotypes of Glioblastoma Cells by Increasing miR-34a and Deregulating the DRD4/Akt/mTOR Signaling Axis. Cancers (Basel). 2019;11(10). pii: E1442. doi:10.3390/cancers11101442.

25. Chi AS, Tarapore RS, Hall MD, Shonka N, Gardner S, Umemura Y, Sumrall A, Khatib Z, Mueller S, Kline C, Zaky W, Khatua S, Weathers SP, Odia Y, Niazi TN, Daghistani D, Cherrick I, Korones D, Karajannis MA, Kong XT, Minturn J, Waanders A, Arillaga-Romany I, Batchelor T, Wen PY, Merdinger K, Schalop L, Stogniew M, Allen JE, Oster W, Mehta MP. Pediatric and adult H3 K27M-mutant diffuse midline glioma treated with the selective DRD2 antagonist ONC201. J Neurooncol. 2019;145(1):97-105. doi:10.1007/s11060-019-03271-3.

26. Arrillaga-Romany I, Odia Y, Prabhu VV, Tarapore RS, Merdinger K, Stogniew M, Oster W, Allen JE, Mehta M, Batchelor TT, Wen PY. Biological activity of weekly ONC201 in adult recurrent glioblastoma patients. Neuro Oncol. 2020;22(1):94-102. doi:10.1093/neuonc/noz164.

27. Int J Neuropsychopharmacol. 2008;11(2):197-205. Wanigasooriya K, Tyler R, Barros-Silva JD, Sinha Y, Ismail T, Beggs AD. Radiosensitising Cancer Using Phosphatidylinositol-3-Kinase (PI3K), Protein Kinase B (AKT) or Mammalian Target of Rapamycin (mTOR) Inhibitors. Cancers (Basel). 2020;12(5):1278. doi:10.3390/cancers12051278.

28. Majewska E, Szeliga M. AKT/GSK3ß Signaling in Glioblastoma. Neurochem Res. 2017;42(3):918-924. doi:10.1007/s11064-016-2044-4.

29. Li X, Wu C, Chen N, Gu H, Yen A, Cao L, Wang E, Wang L. PI3K/Akt/mTOR signaling pathway and targeted therapy for glioblastoma. Oncotarget. 2016;7(22):33440-50. doi:10.18632/oncotarget.7961. 
30. Weissenrieder JS, Reed JL, Green MV, Moldovan GL, Koubek EJ, Neighbors JD, Hohl RJ. The Dopamine D2 Receptor Contributes to the Spheroid Formation Behavior of U87 Glioblastoma Cells. Pharmacology. 2019:1-9. doi:10.1159/000502562.

31. Shaw V, Srivastava S, Srivastava SK. Repurposing antipsychotics of the diphenylbutylpiperidine class for cancer therapy. Semin Cancer Biol. 2019:S1044-579X(19)30144-0. doi:10.1016/j.semcancer.2019.10.007.

32. Platel JC, Bordey A. The multifaceted subventricular zone astrocyte: From a metabolic and pro-neurogenic role to acting as a neural stem cell. Neuroscience. 2016;323:20-8. doi:10.1016/j.neuroscience.2015.10.053.

33. Altmann C, Keller S, Schmidt MHH. The Role of SVZ Stem Cells in Glioblastoma. Cancers (Basel). 2019;11(4). pii: E448. doi:10.3390/cancers11040448.

34. Kast RE, Ellingson BM, Marosi C, Halatsch ME. Glioblastoma treatment using perphenazine to block the subventricular zone's tumor trophic functions. J Neurooncol. 2014;116(2):207-12. doi:10.1007/s11060013-1308-y.

35. Kim Y, Wang WZ, Comte I, Pastrana E, Tran PB, Brown J, Miller RJ, Doetsch F, Molnár Z, Szele FG. Dopamine stimulation of postnatal murine subventricular zone neurogenesis via the D3 receptor. J Neurochem. 2010;114(3):750-60. doi:10.1111/j.1471-4159.2010.06799.x.

36. Kwan K, Schneider JR, Patel NV, Boockvar JA. Tracing the Origin of Glioblastoma: Subventricular Zone Neural Stem Cells. Neurosurgery. 2019;84(1):E15-E16. doi:10.1093/neuros/nyy512.

37. Lao CL, Lu CS, Chen JC. Dopamine D3 receptor activation promotes neural stem/progenitor cell proliferation through AKT and ERK1/2 pathways and expands type-B and -C cells in adult subventricular zone. Glia. 2013;61(4):475-89. doi:10.1002/glia.22449.

38. Merlo S, Canonico PL, Sortino MA. Distinct effects of pramipexole on the proliferation of adult mouse sub-ventricular zone-derived cells and the appearance of a neuronal phenotype. Neuropharmacology. 2011;60(6):892-900. doi:10.1016/j.neuropharm.2011.01.026.

39. Mistry AM, Kelly PD, Gallant JN, Mummareddy N, Mobley BC, Thompson RC, Chambless LB. Comparative Analysis of Subventricular Zone Glioblastoma Contact and Ventricular Entry During Resection in Predicting Dissemination, Hydrocephalus, and Survival. Neurosurgery. 2019;85(5):E924-E932. doi:10.1093/neuros/nyz144.

40. Mistry AM, Wooten DJ, Davis LT, Mobley BC, Quaranta V, Ihrie RA. Ventricular-Subventricular Zone Contact by Glioblastoma is Not Associated with Molecular Signatures in Bulk Tumor Data. Sci Rep. 2019;9(1):1842. doi:10.1038/s41598-018-37734-w.

41. Salvi R, Steigleder T, Schlachetzki JC, Waldmann E, Schwab S, Winner B, Winkler J, Kohl Z. Distinct Effects of Chronic Dopaminergic Stimulation on Hippocampal Neurogenesis and Striatal Doublecortin Expression in Adult Mice. Front Neurosci. 2016;10:77. doi:10.3389/fnins.2016.00077.

42. Winner B, Desplats P, Hagl C, Klucken J, Aigner R, Ploetz S, Laemke J, Karl A, Aigner L, Masliah E, Buerger E, Winkler J. Dopamine receptor activation promotes adult neurogenesis in an acute Parkinson model. Exp Neurol. 2009;219(2):543-52. doi:10.1016/j.expneurol.2009.07.013.

43. Lee JH, Lee JE, Kahng JY, Kim SH, Park JS, Yoon SJ, Um JY, Kim WK, Lee JK, Park J, Kim EH, Lee JH, Lee JH, Chung WS, Ju YS, Park SH, Chang JH, Kang SG, Lee JH. Human glioblastoma arises from subventricular zone cells with low-level driver mutations. Nature. 2018;560(7717):243-247. doi:10.1038/s41586-018-0389-3.

44. Matarredona ER, Pastor AM. Neural Stem Cells of the Subventricular Zone as the Origin of Human Glioblastoma Stem Cells. Therapeutic Implications. Front Oncol. 2019;9:779. doi:10.3389/fonc.2019.00779. 
45. Cameron BD, Traver G, Roland JT, Brockman AA, Dean D, Johnson L, Boyd K, Ihrie RA, Freeman ML. Bcl2-Expressing Quiescent Type B Neural Stem Cells in the Ventricular-Subventricular Zone Are Resistant to Concurrent Temozolomide/X-Irradiation. Stem Cells. 2019;37(12):1629-1639. doi:10.1002/stem.3081.

46. Zarco N, Norton E, Quiñones-Hinojosa A, Guerrero-Cázares H. Overlapping migratory mechanisms between neural progenitor cells and brain tumor stem cells. Cell Mol Life Sci. 2019;76(18):3553-3570. doi:10.1007/s00018-019-03149-7.

47. Berendsen S, van Bodegraven E, Seute T, Spliet WGM, Geurts M, Hendrikse J, Schoysman L, Huiszoon WB, Varkila M, Rouss S, Bell EH, Kroonen J, Chakravarti A, Bours V, Snijders TJ, Robe PA. Adverse prognosis of glioblastoma contacting the subventricular zone: Biological correlates. PLoS One. 2019;14(10):e0222717. doi:10.1371/journal.pone.0222717.

48. Lukacova K, Pavukova E, Kostal L, Bilcik B, Kubikova L. Dopamine D3 receptors modulate the rate of neuronal recovery, cell recruitment in Area X, and song tempo after neurotoxic damage in songbirds. Neuroscience. 2016;331:158-68. doi:10.1016/j.neuroscience.2016.06.032.

49. Bacqué-Cazenave J, Bharatiya R, Barrière G, Delbecque JP, Bouguiyoud N, Di Giovanni G, Cattaert D, De Deurwaerdère P. Serotonin in Animal Cognition and Behavior. Int J Mol Sci. 2020;21(5). pii:E1649. doi:10.3390/ijms21051649.

50. Lieb K, Biersack L, Waschbisch A, Orlikowski S, Akundi RS, Candelario-Jalil E, Hüll M, Fiebich BL. Serotonin via 5-HT7 receptors activates p38 mitogen-activated protein kinase and protein kinase C epsilon resulting in interleukin-6 synthesis in human U373 MG astrocytoma cells. J Neurochem. 2005;93(3):549-59.

51. Mahé C, Bernhard M, Bobirnac I, Keser C, Loetscher E, Feuerbach D, Dev KK, Schoeffter P. Functional expression of the serotonin 5-HT7 receptor in human glioblastoma cell lines. Br J Pharmacol. 2004;143(3):40410.

52. Kast RE. Glioblastoma chemotherapy adjunct via potent serotonin receptor-7 inhibition using currently marketed high-affinity antipsychotic medicines. Br J Pharmacol. 2010;161(3):481-7. doi:10.1111/j.14765381.2010.00923.x.

53. Du X, Wang T, Wang Z, Wu X, Gu Y, Huang Q, Wang J, Xie J. 5-HT7 Receptor Contributes to Proliferation, Migration and Invasion in NSCLC Cells. Onco Targets Ther. 2020;13:2139-2151. doi.10.2147/OTT.S244339

54. Svejda B, Kidd M, Timberlake A, Harry K, Kazberouk A, Schimmack S, Lawrence B, Pfragner R, Modlin IM. Serotonin and the 5-HT7 receptor: the link between hepatocytes, IGF-1 and small intestinal neuroendocrine tumors. Cancer Sci. 2013;104(7):844-55. doi:10.1111/cas.12174.

55. Fatima S, Shi X, Lin Z, Chen GQ, Pan XH, Wu JC, Ho JW, Lee NP, Gao H, Zhang G, Lu A, Bian ZX. 5 -Hydroxytryptamine promotes hepatocellular carcinoma proliferation by influencing $\beta$-catenin. Mol Oncol. 2016;10(2):195-212. doi:10.1016/j.molonc.2015.09.008.

56. Gautam J, Bae YK, Kim JA. Up-regulation of cathepsin S expression by HSP90 and 5-HT(7) receptordependent serotonin signaling correlates with triple negativity of human breast cancer. Breast Cancer Res Treat. 2017;161(1):29-40. doi:10.1007/s10549-016-4027-1.

57. Gautam J, Banskota S, Regmi SC, Ahn S, Jeon YH, Jeong H, Kim SJ, Nam TG, Jeong BS, Kim JA. Tryptophan hydroxylase 1 and 5-HT(7) receptor preferentially expressed in triple-negative breast cancer promote cancer progression through autocrine serotonin signaling. Mol Cancer. 2016;15(1):75. doi:10.1186/s12943016-0559-6

58. Mazhar S, Taylor SE, Sangodkar J, Narla G. Targeting PP2A in cancer: Combination therapies. Biochim Biophys Acta Mol Cell Res. 2019;1866(1):51-63. doi:10.1016/j.bbamcr.2018.08.020. 
59. Moura M, Conde C. Phosphatases in Mitosis: Roles and Regulation. Biomolecules. 2019;9(2). pii: E55. doi:10.3390/biom9020055.

60. Casey SC, Tong L, Li Y, Do R, Walz S, Fitzgerald KN, Gouw AM, Baylot V, Gütgemann I, Eilers M, Felsher DW. MYC regulates the antitumor immune response through CD47 and PD-L1. Science. 2016;352(6282):227-31. doi:10.1126/science.aac9935.

61. Sangodkar J, Farrington CC, McClinch K, Galsky MD, Kastrinsky DB, Narla G. All roads lead to PP2A: exploiting the therapeutic potential of this phosphatase. FEBS J. 2016;283(6):1004-24. doi:10.1111/febs.13573.

62. Tomiyama A, Kobayashi T, Mori K, Ichimura K. Protein Phosphatases-A Touchy Enemy in the Battle Against Glioblastomas: A Review. Cancers (Basel). 2019;11(2). pii:E241. doi:10.3390/cancers11020241.

63. Palanichamy K, Kanji S, Gordon N, Thirumoorthy K, Jacob JR, Litzenberg KT, Patel D, Chakravarti A. NNMT Silencing Activates Tumor Suppressor PP2A, Inactivates Oncogenic STKs, and Inhibits Tumor Forming Ability. Clin Cancer Res. 2017;23(9):2325-2334. doi:10.1158/1078-0432.CCR-16-1323.

64. Ruvolo PP. The broken "Off" switch in cancer signaling: PP2A as a regulator of tumorigenesis, drug resistance, and immune surveillance. BBA Clin. 2016;6:87-99. doi:10.1016/j.bbacli.2016.08.002.

65. Dedobbeleer M, Willems E, Freeman S, Lombard A, Goffart N, Rogister B. Phosphatases and solid tumors: focus on glioblastoma initiation, progression and recurrences. Biochem J. 2017;474(17):2903-2924. doi:10.1042/BCJ20170112.

66. Kaur A, Denisova OV, Qiao X, Jumppanen M, Peuhu E, Ahmed SU, Raheem O, Haapasalo H, Eriksson J, Chalmers AJ, Laakkonen P, Westermarck J. PP2A Inhibitor PME-1 Drives Kinase Inhibitor Resistance in Glioma Cells. Cancer Res. 2016;76(23):7001-7011. doi: 10.1158/0008-5472.CAN-16-1134.

67. Westermarck J. Targeted therapies don`t work for a reason; the neglected tumor suppressor phosphatase PP2A strikes back. FEBS J. 2018;285(22):4139-4145. doi:10.1111/febs.14617.

68. Kauko O, Westermarck J. Non-genomic mechanisms of protein phosphatase 2A (PP2A) regulation in cancer. Int J Biochem Cell Biol. 2018;96:157-164. doi:10.1016/j.biocel.2018.01.005.

69. Zrelli H, Matsuka M, Araki M, Zarrouk M, Miyazaki H. Hydroxytyrosol induces vascular smooth muscle cells apoptosis through NO production and PP2A activation with subsequent inactivation of Akt. Planta Med. 2011;77(15):1680-6. doi:10.1055/s-0030-1271073.

70. Tzadok S, Beery E, Israeli M, Uziel O, Lahav M, Fenig E, Gil-Ad I, Weizman A, Nordenberg J. In vitro novel combinations of psychotropics and anti-cancer modalities in U87 human glioblastoma cells. Int J Oncol. 2010;37(4):1043-51. doi:10.3892/ijo_00000756.

71. Pitre A, Davis N, Paul M, Orr AW, Skalli O. Synemin promotes AKT-dependent glioblastoma cell proliferation by antagonizing PP2A. Mol Biol Cell. 2012;23(7):1243-53. doi:10.1091/mbc.E11-08-0685.

72. Farrington CC, Yuan E, Mazhar S, Izadmehr S, Hurst L, Allen-Petersen BL, Janghorban M, Chung E, Wolczanski G, Galsky M, Sears R, Sangodkar J, Narla G. Protein phosphatase 2A activation as a therapeutic strategy for managing MYC-driven cancers. J Biol Chem. 2020;295(3):757-770. doi:10.1074/jbc.RA119.011443.

73. Hutter S, Bolin S, Weishaupt H, Swartling FJ. Modeling and Targeting MYC Genes in Childhood Brain Tumors. Genes (Basel). 2017;8(4).pii:E107. doi:10.3390/genes8040107.

74. Wang G, Wang J, Zhao H, Wang J, Tony To SS. The role of Myc and let-7a in glioblastoma, glucose metabolism and response to therapy. Arch Biochem Biophys. 2015;580:84-92. doi:10.1016/j.abb.2015.07.005.

75. Xin M, Deng X. Protein phosphatase 2A enhances the proapoptotic function of Bax through dephosphorylation. J Biol Chem. 2006;281(27):18859-67. 
76. Tsuji S, Yabe R, Usui T, Mizuno T, Ohama T, Sato K. Anti-tumor effects of perphenazine on canine lymphoma. J Vet Med Sci. 2016;78(8):1293-8. doi:10.1292/jvms.15-0707.

77. Gutierrez A, Pan L, Groen RW, Baleydier F, Kentsis A, Marineau J, Grebliunaite R, Kozakewich E, Reed C, Pflumio F, Poglio S, Uzan B, Clemons P, VerPlank L, An F, Burbank J, Norton S, Tolliday N, Steen H, Weng AP, Yuan H, Bradner JE, Mitsiades C, Look AT, Aster JC. Phenothiazines induce PP2A-mediated apoptosis in T cell acute lymphoblastic leukemia. J Clin Invest. 2014;124(2):644-55. doi:10.1172/JCI65093.

78. Ramaswamy K, Spitzer B, Kentsis A. Therapeutic Re-Activation of Protein Phosphatase 2A in Acute Myeloid Leukemia. Front Oncol. 2015;5:16. doi:10.3389/fonc.2015.00016.

79. Morita K, He S, Nowak RP, Wang J, Zimmerman MW, Fu C, Durbin AD, Martel MW, Prutsch N, Gray NS, Fischer ES, Look AT. Allosteric Activators of Protein Phosphatase 2A Display Broad Antitumor Activity Mediated by Dephosphorylation of MYBL2. Cell. 2020;181(3):702-715.e20. doi:10.1016/j.cell.2020.03.051.

80. Omoruyi SI, Ekpo OE, Semenya DM, Jardine A, Prince S. Exploitation of a novel phenothiazine derivative for its anti-cancer activities in malignant glioblastoma. Apoptosis. 2020;25(3-4):261-274. doi:10.1007/s10495020-01594-5.

81. Stupp R, Mason WP, van den Bent MJ, Weller M, Fisher B, Taphoorn MJ, Belanger K, Brandes AA, Marosi C, Bogdahn U, Curschmann J, Janzer RC, Ludwin SK, Gorlia T, Allgeier A, Lacombe D, Cairncross JG, Eisenhauer E, Mirimanoff RO; European Organisation for Research and Treatment of Cancer Brain Tumor and Radiotherapy Groups; National Cancer Institute of Canada Clinical Trials Group. Radiotherapy plus concomitant and adjuvant temozolomide for glioblastoma. N Engl J Med. 2005;352(10):987-96. doi:10.1056/NEJMoa043330.

82. Coomans M, Dirven L, K Aaronson N, Baumert BG, van den Bent M, Bottomley A, Brandes AA, Chinot O, Coens C, Gorlia T, Herrlinger U, Keime-Guibert F, Malmström A, Martinelli F, Stupp R, Talacchi A, Weller M, Wick W, Reijneveld JC, Taphoorn MJB; EORTC Quality of Life Group and the EORTC Brain Tumor Group. The added value of health-related quality of life as a prognostic indicator of overall survival and progression-free survival in glioma patients: a meta-analysis based on individual patient data from randomised controlled trials. Eur J Cancer. 2019;116:190-198. doi:10.1016/j.ejca.2019.05.012.

83. Lind B, Breivik H. Metoclopramide and perphenazine in the prevention of postoperative nausea and vomiting. Br J Anaesth. 1970;42(7):614-7.

84. Desilva PH, Darvish AH, McDonald SM, Cronin MK, Clark K. The efficacy of prophylactic ondansetron, droperidol, perphenazine, and metoclopramide in the prevention of nausea and vomiting after major gynecologic surgery. Anesth Analg. 1995;81(1):139-43.

85. Dundee JW, Loan WB, Morrison JD. A comparison of the efficacy of cyclizine and perphenazine in reducing the emetic effects of morphine and pethidine. Br J Clin Pharmacol. 1975;2(1):81-5.

86. Purkis IE. The action of thiethylperazine (Torecan), a new anti-emetic, compared with perphenazine (Trilafon), trimethobenzamide (Tigan), and a placebo in the suppression of postanaesthetic nausea and vomiting. Can Anaesth Soc J. 1965;12(6):595-607.

87. Williams BA, Kentor ML, Skledar SJ, Orebaugh SL, Vallejo MC. Routine multimodal antiemesis including low-dose perphenazine in an ambulatory surgery unit of a university hospital: a 10-year history. Supplement to: Eliminating postoperative nausea and vomiting in outpatient surgery with multimodal strategies including low doses of nonsedating, off-patent antiemetics: is "zero tolerance" achievable? Scientific World Journal. 2007;7:978-86. doi:10.1100/tsw.2007.132

88. Steinbrook RA, Gosnell JL, Freiberger D. Prophylactic antiemetics for laparoscopic cholecystectomy: a comparison of perphenazine, droperidol plus ondansetron, and droperidol plus metoclopramide. J Clin Anesth. 1998;10(6):494-8. 
89. Pileggi DJ, Cook AM. Neuroleptic Malignant Syndrome. Ann Pharmacother. 2016;50(11):973-981. doi:10.1177/1060028016657553.

90. Nisijima K. Serotonin syndrome overlapping with neuroleptic malignant syndrome: A case report and approaches for differentially diagnosing the two syndromes. Asian J Psychiatr. 2015;18:100-1. doi:10.1016/j.ajp.2015.10.003.

91. Kaufman KR, Levitt MJ, Schiltz JF, Sunderram J. Neuroleptic malignant syndrome and serotonin syndrome in the critical care setting: case analysis. Ann Clin Psychiatry. 2006;18(3):201-4.

92. Perry PJ, Wilborn CA. Serotonin syndrome vs neuroleptic malignant syndrome: a contrast of causes, diagnoses, and management. Ann Clin Psychiatry. 2012;24(2):155-62.

93. Sokoro AA, Zivot J, Ariano RE. Neuroleptic malignant syndrome versus serotonin syndrome: the search for a diagnostic tool. Ann Pharmacother. 2011;45(9):e50. doi:10.1345/aph.1P787.

94. van Rensburg R, Decloedt EH. An Approach to the Pharmacotherapy of Neuroleptic Malignant Syndrome. Psychopharmacol Bull. 2019;49(1):84-91.

95. Perera V, Bies RR, Mo G, Dolton MJ, Carr VJ, McLachlan AJ, Day RO, Polasek TM, Forrest A. Optimal sampling of antipsychotic medicines: a pharmacometric approach for clinical practice. Br J Clin Pharmacol. 2014;78(4):800-14. doi:10.1111/bcp.12410.

96. Jin Y, Pollock BG, Coley K, Miller D, Marder SR, Florian J, Schneider L, Lieberman J, Kirshner M, Bies RR. Population pharmacokinetics of perphenazine in schizophrenia patients from CATIE: impact of race and smoking. J Clin Pharmacol. 2010;50(1):73-80. doi:10.1177/0091270009343694.

97. Eggert Hansen C, Rosted Christensen T, Elley J, Bolvig Hansen L, Kragh-Sorensen P, Larsen NE, Naestoft J, Hvidberg EF. Clinical pharmacokinetic studies of perphenazine. Br J Clin Pharmacol. 1976;3(5):91523.

98. Haffner F. Perphenazine serum levels in patients on standard doses. Psychopharmacol Ser. 1989;7:280-3.

99. Jönsson AK, Spigset O, Reis M. A Compilation of Serum Concentrations of 12 Antipsychotic Drugs in a Therapeutic Drug Monitoring Setting. Ther Drug Monit. 2019;41(3):348-356. doi:10.1097/FTD.0000000000000585.

100. Schnabel A, Eberhart LH, Muellenbach R, Morin AM, Roewer N, Kranke P. Efficacy of perphenazine to prevent postoperative nausea and vomiting: a quantitative systematic review. Eur J Anaesthesiol. 2010;27(12):1044-51. doi:10.1097/EJA.0b013e32833b7969.

101. Gupta MA, Vujcic B, Pur DR, Gupta AK. Use of antipsychotic drugs in dermatology. Clin Dermatol. 2018;36(6):765-773. doi:10.1016/j.clindermatol.2018.08.006.

102. Hartung B, Sampson S, Leucht S. Perphenazine for schizophrenia. Cochrane Database Syst Rev. 2015;(3):CD003443. doi:10.1002/14651858.CD003443.pub3.

103. Sweet RA, Pollock BG, Mulsant BH, Rosen J, Sorisio D, Kirshner M, Henteleff R, DeMichele MA. Pharmacologic profile of perphenazine's metabolites. J Clin Psychopharmacol. 2000;20(2):181-7.

104. Kim MS, Yoo BC, Yang WS, Han SY, Jeong D, Song JM, Kim KH, Aravinthan A, Kim JH, Kim JH, Kim SC, Cho JY. Src is the primary target of aripiprazole, an atypical antipsychotic drug, in its anti-tumor action. Oncotarget. 2017;9(5):5979-5992. doi:10.18632/oncotarget.23192.

105. Suzuki S, Yamamoto M, Sanomachi T, Togashi K, Sugai A, Seino S, Yoshioka T, Kitanaka C, Okada M. Brexpiprazole, a Serotonin-Dopamine Activity Modulator, Can Sensitize Glioma Stem Cells to Osimertinib, a Third-Generation EGFR-TKI, via Survivin Reduction. Cancers (Basel). 2019;11(7).pii: E947. doi:10.3390/cancers11070947. 
106. Pinheiro T, Otrocka M, Seashore-Ludlow B, Rraklli V, Holmberg J, Forsberg-Nilsson K, Simon A, Kirkham M. A chemical screen identifies trifluoperazine as an inhibitor of glioblastoma growth. Biochem Biophys Res Commun. 2017;494(3-4):477-483. doi:10.1016/j.bbrc.2017.10.106.

107. Oliva CR, Zhang W, Langford C, Suto MJ, Griguer CE. Repositioning chlorpromazine for treating chemoresistant glioma through the inhibition of cytochrome c oxidase bearing the COX4-1 regulatory subunit. Oncotarget. 2017;8(23):37568-37583. doi:10.18632/oncotarget.17247.

108. Abbruzzese C, Matteoni S, Persico M, Villani V, Paggi MG. Repurposing chlorpromazine in the treatment of glioblastoma multiforme: analysis of literature and forthcoming steps. J Exp Clin Cancer Res. 2020;39(1):26. doi:10.1186/s13046-020-1534-z.

109. Berghauser Pont LM, Balvers RK, Kloezeman JJ, Nowicki MO, van den Bossche W, Kremer A, Wakimoto H, van den Hoogen BG, Leenstra S, Dirven CM, Chiocca EA, Lawler SE, Lamfers ML. In vitro screening of clinical drugs identifies sensitizers of oncolytic viral therapy in glioblastoma stem-like cells. Gene Ther. 2015;22(12):947-59. doi:10.1038/gt.2015.72.

110. Dong Y, Furuta T, Sabit H, Kitabayashi T, Jiapaer S, Kobayashi M, Ino Y, Todo T, Teng L, Hirao A, Zhao SG, Nakada M. Identification of antipsychotic drug fluspirilene as a potential anti-glioma stem cell drug. Oncotarget. 2017;8(67):111728-111741. doi:10.18632/oncotarget.22904.

111. Johannessen TC, Hasan-Olive MM, Zhu H, Denisova O, Grudic A, Latif MA, Saed H, Varughese JK, Røsland GV, Yang N, Sundstrøm T, Nordal A, Tronstad KJ, Wang J, Lund-Johansen M, Simonsen A, Janji B, Westermarck J, Bjerkvig R, Prestegarden L. Thioridazine inhibits autophagy and sensitizes glioblastoma cells to temozolomide. Int J Cancer. 2019;144(7):1735-1745. doi:10.1002/ijc.31912.

112. Mégalizzi V, Decaestecker C, Debeir O, Spiegl-Kreinecker S, Berger W, Lefranc F, Kast RE, Kiss R. Screening of anti-glioma effects induced by sigma-1 receptor ligands: potential new use for old psychiatric medicines. Eur J Cancer. 2009;45(16):2893-905. doi:10.1016/j.ejca.2009.07.011.

113. Hua J, Olsson AR, Pero RW. Neutral metoclopramide sensitizes cytotoxicity induced by ionizing radiation in SCID mice xenografted with a human brain astrocytoma. Int J Cancer. 1997;73(6):871-4.

114. Olsson A, Sheng Y, Kjellén E, Pero RW. In vivo tumor measurement of DNA damage, DNA repair and NAD pools as indicators of radiosensitization by metoclopramide. Carcinogenesis. 1995;16(5):1029-35.

115. Salford LG, Pero RW, Aas AT, Brun A. Metoclopramide as a sensitizer of 1,3-bis(2-chloroethyl)-1nitrosourea treatment of brain tumors in the rat. Anticancer Drugs. 1992;3(3):267-72.

116. Karpel-Massler G, Kast RE, Westhoff MA, Dwucet A, Welscher N, Nonnenmacher L, Hlavac M, Siegelin MD, Wirtz CR, Debatin KM, Halatsch ME. Olanzapine inhibits proliferation, migration and anchorage independent growth in human glioblastoma cell lines and enhances TMZ's antiproliferative effect. J Neurooncol. 2015;122:21-33. doi:10.1007/s11060-014-1688-7.

117. Wang YX, Xu SQ, Chen XH, Liu RS, Liang ZQ. Autophagy involvement in olanzapine-mediated cytotoxic effects in human glioma cells. Asian Pac J Cancer Prev. 2014;15(19):8107-13.

118. Ranjan A, Wright S, Srivastava SK. Immune consequences of penfluridol treatment associated with inhibition of glioblastoma tumor growth. Oncotarget. 2017;8(29):47632-47641. doi:10.18632/oncotarget.17425.

119. Ranjan A, Srivastava SK. Penfluridol suppresses glioblastoma tumor growth by Akt-mediated inhibition of GLI1. Oncotarget. 2017;8(20):32960-32976. doi:10.18632/oncotarget.16515.

120. Kim H, Chong K, Ryu BK, Park KJ, Yu MO, Lee J, Chung S, Choi S, Park MJ, Chung YG, Kang SH. Repurposing Penfluridol in Combination with Temozolomide for the Treatment of Glioblastoma. Cancers (Basel). 2019;11(9).pii:E1310. doi:10.3390/cancers11091310.

121. Srivastava S, Zahra FT, Gupta N, Tullar PE, Srivastava SK, Mikelis CM. Low Dose of Penfluridol Inhibits VEGF-Induced Angiogenesis. Int J Mol Sci. 2020;21(3).pii:E755. doi:10.3390/ijms21030755. 
122. Zielke S, Meyer N, Mari M, Abou-El-Ardat K, Reggiori F, van Wijk SJL, Kögel D, Fulda S. Loperamide, pimozide, and STF-62247 trigger autophagy-dependent cell death in glioblastoma cells. Cell Death Dis. 2018;9(10):994. doi:10.1038/s41419-018-1003-1.

123. Gonçalves JM, Silva CAB, Rivero ERC, Cordeiro MMR. Inhibition of cancer stem cells promoted by Pimozide. Clin Exp Pharmacol Physiol. 2019;46(2):116-125. doi:10.1111/1440-1681.13049.

124. Faraz S, Pannullo S, Rosenblum M, Smith A, Wernicke AG. Long-term survival in a patient with glioblastoma on antipsychotic therapy for schizophrenia: a case report and literature review. Ther Adv Med Oncol. 2016;8(6):421-428. doi:10.1177/1758834016659791.

125. Wang Y, Huang N, Li H, Liu S, Chen X, Yu S, Wu N, Bian XW, Shen HY, Li C, Xiao L. Promoting oligodendroglial-oriented differentiation of glioma stem cell: a repurposing of quetiapine for the treatment of malignant glioma. Oncotarget. 2017;8(23):37511-37524. doi:10.18632/oncotarget.16400.

126. Skaga E, Skaga IØ, Grieg Z, Sandberg CJ, Langmoen IA, Vik-Mo EO. The efficacy of a coordinated pharmacological blockade in glioblastoma stem cells with nine repurposed drugs using the CUSP9 strategy. J Cancer Res Clin Oncol. 2019;145(6):1495-1507. doi:10.1007/s00432-019-02920-4.

127. Chu CW, Ko HJ, Chou CH, Cheng TS, Cheng HW, Liang YH, Lai YL, Lin CY, Wang C, Loh JK, Cheng JT, Chiou SJ, Su CL, Huang CF, Hong YR. Thioridazine Enhances P62-Mediated Autophagy and Apoptosis Through Wnt/ $\beta$-Catenin Signaling Pathway in Glioma Cells. Int J Mol Sci. 2019;20(3). pii: E473. doi:10.3390/ijms20030473.

128. Cheng HW, Liang YH, Kuo YL, Chuu CP, Lin CY, Lee MH, Wu AT, Yeh CT, Chen EI, Whang-Peng J, Su CL, Huang CY. Identification of thioridazine, an antipsychotic drug, as an antiglioblastoma and anticancer stem cell agent using public gene expression data. Cell Death Dis. 2015;6:e1753. doi:10.1038/cddis.2015.77.

129. Kang S, Lee JM, Jeon B, Elkamhawy A, Paik S, Hong J, Oh SJ, Paek SH, Lee CJ, Hassan AHE, Kang SS, Roh EJ. Repositioning of the antipsychotic trifluoperazine: Synthesis, biological evaluation and in silico study of trifluoperazine analogs as anti-glioblastoma agents. Eur J Med Chem. 2018;151:186-198. doi:10.1016/j.ejmech.2018.03.055.

130. Zhang X, Xu R, Zhang C, Xu Y, Han M, Huang B, Chen A, Qiu C, Thorsen F, Prestegarden L, Bjerkvig R, Wang J, Li X. Trifluoperazine, a novel autophagy inhibitor, increases radiosensitivity in glioblastoma by impairing homologous recombination. J Exp Clin Cancer Res. 2017;36(1):118. doi:10.1186/s13046-017-0588$\mathrm{z}$.

131. Ramis G, Villalonga-Planells R, Serra-Sitjar M, Brell M, Fernández de Mattos S, Villalonga P. The tumor suppressor FOXO3a mediates the response to EGFR inhibition in glioblastoma cells. Cell Oncol (Dordr). 2019;42(4):521-536. doi:10.1007/s13402-019-00443-1.

132. Omoruyi SI, Ekpo OE, Semenya DM, Jardine A, Prince S. Exploitation of a novel phenothiazine derivative for its anti-cancer activities in malignant glioblastoma. Apoptosis. 2020;25(3-4):261-274. doi:10.1007/s10495-020-01594-5.

133. Bhat K, Saki M, Vlashi E, Cheng F, Duhachek-Muggy S, Alli C, Yu G, Medina P, He L, Damoiseaux R, Pellegrini M, Zemke NR, Nghiemphu PL, Cloughesy TF, Liau LM, Kornblum HI, Pajonk F. The dopamine receptor antagonist trifluoperazine prevents phenotype conversion and improves survival in mouse models of glioblastoma. Proc Natl Acad Sci U S A. 2020;117(20):11085-11096. doi:10.1073/pnas.1920154117.

Table 1. Basic pharmacological parameters of perphenazine.

\begin{tabular}{lll}
\hline Mol. wt. & $404 \mathrm{Da}, 1 \mathrm{nmol}=404 \mathrm{ng}$ \\
\hline metabolism & CYP2D6, CYP1A2 (minor) & 96 \\
psychiatric dose & 4 to $32 \mathrm{mg} / \mathrm{d}$ & 96
\end{tabular}




\begin{tabular}{lll}
\hline Mol. wt. & 404 Da, 1 nmol = 404 ng & \\
\hline metabolites & Perphenazine sulfoxide, Dealkyl & 96 \\
& perphenazine & \\
half-life & $\sim 10$ hours, blood & 96,97 \\
common blood level & 1 to $10 \mathrm{nmol} / \mathrm{L} 1.5 \mathrm{ng} / \mathrm{ml}$ & $98,99,103$ \\
& perphenazine $=3.7 \mathrm{nmol} / \mathrm{L} 0.8$ & \\
& ng/ml perphenazine sulfoxide, 2.0 & \\
& ng/ml dealkyl perphenazine & 102 \\
Side effects $>5 \%$ & day sedation at $>8 \mathrm{mg} /$ day & 102 \\
Side effects $1-5 \%$ & akathisia, hyperprolactinemia, & \\
& hypotension, sexual & \\
& dysfunction, mainly at $>8 \mathrm{mg} / \mathrm{d}$ & \\
Side effects $<1 \%$ & neuroleptic malignant syndrome & 89 \\
psychiatric use & antipsychotic, antidepressant & 102 \\
& augmentation, agitation states & \\
other uses & anti-nausea, antipruritic, & $84,100,101$ \\
& anti-vertigo & \\
\hline
\end{tabular}

Table 2. List of marketed and FDA/EMA approved antipsychotic drugs that have shown anti-glioma effects. Remarkably, all 16 block D2 signaling in the brain, albeit with different affinities. All are phenothiazines except for those marked *. Partial D2 antagonist-agonists marked with \#. It has not been proven that it is in fact D2 antagonism that is responsible for anti-glioma effect of these drugs.

\begin{tabular}{ll}
\hline drug & reference \\
\hline aripiprazole $^{*} \#$ & 104 \\
brexpiprazole $^{*} \#$ & 105 \\
chlorpromazine $^{\text {fluphenazine }}$ & $106,107,108$ \\
fluspirilene & 109 \\
haloperidol $^{*}$ & 110 \\
metoclopramide $^{*}$ & 112 \\
olanzapine & $113-115$ \\
penfluridol & 116,117 \\
perphenazine & $22,63,79$, \\
pimozide & 122,123 \\
prochlorperazine & 22 \\
risperidone $*$ & 23,124, \\
quetiapine $*$ & 125,126 \\
thioridazine & $111,127,128,132$ \\
trifluoperazine & $106,129-131,133$ \\
\hline
\end{tabular}

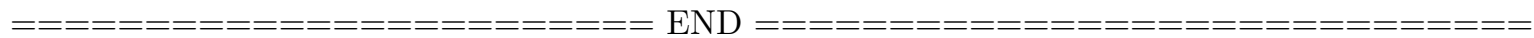

